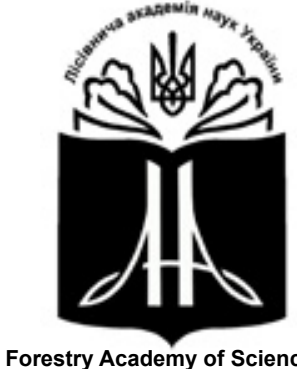
of Ukraine

Наукові праці Лісівничої академії наук України Proceedings of the Forestry Academy of Sciences of Ukraine

http://fasu.nltu.edu.ua https://doi.org/10.15421/411919

Article received 2018.09.18

Article accepted 2019.03.28
ISSN 1991-606X print

ISSN 2616-5015 online

(a) $\triangle$ Correspondence author

Vasyl Yukhnovskyi

yukhnov@ukr.net

General Rodimtsev str., 19, Kyiv, 03041, Ukraine

УДК 502-025.17:711.4

\title{
Оцінка екосистемних послуг у генеральному плануванні міських територій
}

\author{
В.Ю. Юхновський ${ }^{1}$ О. В. Зібцева ${ }^{2}$
}

На основі аналізу літературних джерел і генеральних планів розвитку міст з'ясовано сучасний стан та рівень впровадження концепиії екосистемних послуг у містобудівному плануванні України й окреслено перспективи його інтеграції та розвитку. Обгрунтовано координованість генерального планування із динамікою трансформації землекористування міських територій і вартістю їх екосистемних послуг. Зазначено, щуо оцінювання екосистемних послуг здійснюється за трьома напрямами: екологічним, економічним і сочіальним. Для кожної з груп екосистемних послуг застосовують свої методи оцінювання. Так, забезпечувальні екосистемні послуги найчастіше оцінюють за їх ринковою вартістю, регулятивні-методами «запобігання та заміщення витрат», культурні - методом «витрат на подорож». За результатами аналізу динаміки вартості послуг глобальної екосистеми впродовж 1995-2015 рр. виявлено втрату \$1,21 млрд, щуо свідчить про найбільшу уразливість екорегіонів, у складі яких домінують екостабілізаційні угіддя: ліси, луки, пасовища, води.Обтрунтовано необхідність гармонізації національного екологічного законодавства з європейськими стандартами, впровадження екосистемного підходу в територіальний менеджмент, деоцінювання екосистемних послуг має стати невід'ємним атрибутом територіального планування. Враховуючи, щзо серед індикаторів сталого розвитку ООН є низка показників, пов'язаних із екологічною стійкістю природних комплексів і співвіднесених із екосистемними послугами (наприклад, лісистість), обтрунтовано атрибутивність введення альтернативного нормативного показника для генерального планування міських територій - рівня озеленення міста як містобудівного обмеження.

Ключові слова: сталий розвиток; вартість екосистемних послуг; зелений простір; озеленення.

Вступ. Сталий розвиток - це стабільний соціально-економічний розвиток, що не руйнує своєї природної основи. Згідно з концепцією сталого розвитку пропонують використовувати економічний механізм врегулювання взаємовідносин людини і природи у вигляді оцінювання екосистемних послуг (EП) (Rozenberh, 2014). Сформульоване майже три десятиліття тому поняття оцінки ЕП передбачало забезпечення основи вирішення проблем охорони природи і збереження біорізноманіття (Bodrovetal., 2016). На світовому рівні актуалізуються питання, пов'язані з ефективним управлінням ЕП, які грунтуються на їхньому об'єктивному економічному оцінюванні (Sotnyk \& Mogilenets, 2011). Активно сприяють проведенню наукових досліджень у сфері економічного оцінювання ЕП такі міжнародні організації, як Організація Об'єднаних Націй, Світовий Банк, Всесвітній Фонд Дикої Природи.

У контексті вирішення завдань переходу до сталого розвитку в Україні, як і в інших країнах, останнім часом також приділяють певну увагу запровадженню концепції ЕП, а саме: оцінюванню,

\footnotetext{
Юхновський Василь Юрійович - академік Лісівничої академії наук України, доктор сільськогосподарських наук, професор кафедри відтворення лісів та лісових меліорацій. Національний університет біоресурсів і природокористування України, вул. Генерала Родимцева, 19, м. Київ, 03041, Україна. Тел.: +38-067-720-32-16. E-mail: yukhnov@ukr.net ORCID: http://orcid.org/0000-0003-3182-4347

2 Зібцева Ольга Василівна - кандидат сільськогосподарських наук, доцент кафедри ландшафтної архітектури та садово-паркового будівництва. Національний університет біоресурсів і природокористування України, вул. Генерала Родимцева, 19, м. Київ, 03041, Україна. Тел.: +38-050-835-77-74. E-mail: stplut2017@gmail.com ORCID: http://orcid.org/0000-0003-0706-0738
} 
визначенню величини потенціалу, формуванню й реалізації стратегії держави на внутрішньому i зовнішньому ринках ЕП (Bodrovetal, 2016). Українське законодавство передбачає імплементацію підходу ЕП до 2020 року. ЕП згадуються в Законі України «Про основні засади (стратегію) державної екологічної політики до 2020 року», спрямованому на гармонізацію українського екологічного законодавства з СС і впровадження екосистемного підходу в управлінську практику (Kruhlov, 2018). «Національний план дій з охорони навколишнього природного середовища на 2011-2015 роки» передбачав розробку офіційної методології визначення та класифікації ЕП. Однак наразі обізнаність щодо ЕП низька і не набула поширення навіть у наукових колах. Дотепер немає офіційної методики здійснення оцінювання ЕП та ії інтеграції у територіальне планування.

Згідно з чинним законодавством, Україна перебуває у процесі розроблення офіційних підходів i методик класифікації та монетарної оцінки ЕП. Наукових робіт з цієї тематики обмаль й досі не запропоновано офіційної методики щодо визначення можливих типів ЕП на підставі інвентаризацій i оцінок (Kruhlov, 2018). Втім, як визнає автор, підхід ЕП має стати стандартним компонентом територіального планування.

У більшості країн Свропи концепція ЕП є основою стратегічних планів національної політики збереження та відновлення природних ресурсів (Pakhomovetal, 2018), а перехід суспільства на екологічну парадигму розвитку $є$ важливою умовою реалізації природовідтворення.

Незважаючи на те, що Україна є стороною понад 50 двосторонніх угод і 40 глобальних та регіональних конвенцій, протоколів екологічного спрямування, рівень збалансованості розвитку в Україні дуже низький. Наразі правові засади територіального планування в Україні формуються в полі дії понад ста законодавчих актів й загалом законодавчу базу в сфері територіального планування та містобудівної діяльності можна вважати сформованою, хоча вона має багато недоліків.

У всіх країнах СС планувалося провести картографування та оцінювання ЕП до 2014 року. Натомість Україна досі не має офіційно затвердженої Концепції, Стратегії і Плану дій щодо переходу до сталого розвитку і впровадження його принципів у практику, що, на думку Kononenko (2013), свідчить про невисоку ефективність національної екологічної політики. Найкращі приклади успішного сталого розвитку демонструють Естонія, Чехія, Словаччина, натомість Україна, на жаль, - найгірший, незважаючи на розробку та введення в дію 137 національних, державних, міжнародних, галузевих i регіональних програм, безпосередньо пов'язаних iз сталим розвитком. Kononenko (2013) вважає, що Україна $є$ зовнішньо орієнтованою у сфері політики сталого розвитку та регіональної екологічної політики і констатує повільність переходу на модель сталого розвитку внаслідок недостатнього інститу- ційного забезпечення та низької ефективності механізму державного управління загалом.

Наразі практичний облік ЕП ведеться в багатьох країнах (Koniushkov, 2015). Понад 50 країн прийняли зобов'язання використовувати вартісні оцінки природного капіталу в системах національних рахунків (Titova, 2015). Так, у 2011 р. у Великобританії було завершено оцінювання національних екосистем, в ході якого встановлено тенденції зміни екосистем у ретроспективі за кілька десятиліть. У 2012 р. було завершено загальне оцінювання національних екосистем у скандинавських країнах (Фінляндії, Швеції, Норвегії, Данії, включаючи Гренландію, Ісландію), метою яких було виявлення найкритичніших екосистем та індикацію можливостей використання оцінок ЕП у державних системах охорони природи. Свропейська стратегія біорізноманіття вимагає від усіх країн-учасниць СС до 2020 р. встановити й оцінити на національному рівні екосистеми та їхні послуги, а також інтегрувати отримані результати в загальну систему екологоекономічних розрахунків. План дій передбачає розробку методики класифікації та оцінювання ЕП.

В Україні до 2020 р. екосистемний підхід має бути впроваджено у територіальний менеджмент, а українське екологічне законодавство - гармонізоване 3 європейськими стандартами. Втім Україна у питанні системного обліку ЕП перебуває на самому початку процесу: на відміну від більшості країн, в Україні немає Національної стратегії біорізноманіття, термінологія та методики у сфері екології формувалися ще за радянських та пострадянських часів й наразі не завжди гармоніюють із західними підходами та концептами. Доволі обмеженою є база вихідних даних, що, на наш погляд, є першочерговою проблемою у здійсненні підрахунків вартості ЕП.

Концепція ЕП отримала визнання в національній екологічній політиці та законодавстві багатьох країн, але не в Україні, хоча серед пріоритетних стратегічних завдань екологічної політики нашої держави визначено «формування до 2015 року та подальше застосування вартісного оцінювання ЕП» (Soloviy, 2016).

Сталий розвиток міських територій є основною метою стратегічного планування. Наразі міська система озеленення, зазвичай, планується 3 використанням рекреаційних стандартів, незважаючи на зростання уваги до ЕП. Актуалізація ЕП - не лише чинник забезпечення стійкості, екологічної збалансованості та збереження екосистем, але й убезпечення життєдіяльності людини. 3 огляду на це, оцінка стійкого розвитку природничого потенціалу екосистеми міста стає дедалі необхіднішою.

Об'єкти і методика дослідження. Дослідження здійснено на основі аналізу літературних джерел за допомогою пошукової системи Web of Science (http://webofscience.com) за ключовим словосполученням «city ecosystem services», де були відібрані лише публікації за 2017-2019 рр. Також проаналізовано аналогічні джерела у довільному російськомовному та українськомовному пошуку 
Google за останнє десятиріччя. У дослідженні використано системний підхід, порівняльний аналіз та узагальнення.

Предметом досліджень є концепція ЕП, методологія оцінювання та іiі використання у системі територіального міського планування, зокрема в українських реаліях. Мета дослідження полягає у з'ясуванні реальної ситуації щодо впровадження концепції ЕП у генеральне планування міських територій в Україні.

Загалом оцінювання ЕП здійснюють за трьома напрямами: екологічним, економічним і соціальним (Koniushkov, 2015). Еколого-економічні підходи покликані посилити роль ринкових механізмів у справі захисту навколишнього середовища. При цьому для кожної із груп ЕП використовують свої методи вартісного оцінювання. Забезпечувальні ЕП, частка яких у сукупній вартості ЕП відносно невелика, часто оцінюють за їх ринковою вартістю; регулятивні - методами «запобігання витратам» i «заміщення витрат», культурні - методом «витрат на подорож» та іншими. В основі неринкового оцінювання, зазвичай, покладена готовність сплачувати за певні ЕП, при цьому обов'язковим під час оцінювання ЕП на місцевому рівні вважають системний підхід.

Отже, для кожної групи ЕП існують свої методи вартісного оцінювання. Найпростіші - методи ринкового оцінювання (market price methods), які використовують для відчужуваних забезпечувальних ЕП. Методи оцінювання не ринкових ЕП (переважно регулятивних і культурних), засновані на низці припущень і зазвичай вимагають серйозної статистичної роботи й усвідомлення обмеження цих способів (Costanza et al., 2006).

Для оцінювання ЕП, які не мають реальної ринкової ціни, застосовують метод відновної вартості. Серед інших, можливе також використання для розрахунків експертних оцінок. Метод транспортнодорожніх витрат або витрат на подорож використовують для визначення вартості рекреаційних послуг лісу. Метод умовної вартості використовують, зокрема, для визначення вартості збереження лісами біорізноманіття. Метод перенесення (трансферу) вартості дає змогу здійснювати дослідження в умовах повної відсутності даних, що, на наш погляд, особливо актуально для українських малих міст, де дані 3 інвентаризації зелених насаджень, зазвичай, відсутні.

Група TEEB (The Economics of Ecosystems and Biodiversity) (Sukhdevetal, 2010) визнає, що можна по-різному оцінювати природні блага і використовувати різні методи визначення вартості. Вартісне оцінювання природи залежить від місцевих біофізичних і екологічних умов, а також від соціального, економічного та культурного середовища. Для формування повної економічної картини, крім матеріальних цінностей, потрібно враховувати нематеріальні блага, які можуть виражатися в готовності суспільства платити за збереження рідкісних видів чи ландшафтів, або за захист загальних ресурсів. За- значено, що вартісне оцінювання - це інструмент, що допомагає переналаштувати несправний економічний компас, який призвів до рішень, згубних як для поточного добробуту, так і для добробуту майбутніх поколінь.

Аналіз проблеми та обговорення. Millennium Ecosystem Assessment (MEA) визначає ЕП як вигоди, які люди отримують від екосистем. За класифікацію, запропонованою у звіті МЕА (2005), підготовленому під егідою ООН, ідентифікують чотири групи ЕП: забезпечувальні (provisioning services) - послуги від продукції, яку надають екосистеми: продовольство, вода, деревина, волокно, паливо, генетичні ресурси, питна вода; регулятивні (regulating services) - послуги регулюючих екосистемних процесів: формування клімату, захист від повеней та інших стихійних лих, контроль захворювань, поглинання відходів людської життєдіяльності, очищення води і повітря, боротьба зі шкідниками; культурні (cultural services) - вклад екосистем у збагачення культурних, духовних та естетичних аспектів людського добробуту: емоції від спілкування 3 природою, відчуття місцевості, середовище для формування способу життя, звичаїв і традицій; підтримувальні (supporting services) - послуги, які забезпечують основні екосистемні процеси: формування грунту, первинна продуктивність, базові біогеохімічні процеси (кругообіг поживних речовин, фотосинтез), середовище перебування. Втім, за дослідженнями Common International Classification of Ecosystem Services (Grunewald \& Bastian, 2014, Haines-Young \& Potschin, 2017), підтримувальні послуги введені до складу регулятивних, а залишені три класи відповідають категоріям стійкого розвитку: економічній, екологічній і соціальній (Bodrov et al., 2016).

У 1997 р. глобальну вартість ЕП оцінено в середньому в \$33 трлн/рік у цінах 1995 р. (або \$46 трлн/рік у цінах 2007 р.), що значно перевищувало вартість валового світового продукту в 2000 р. (Costanza, 2014). Вартість глобальних ЕП у 2011 р. становила вже \$125-145 трлн/рік у цінах 2007 року. Причому зниження вартості ЕП внаслідок зміни землекористування за 1997-2011 рр. оцінено у \$4,3-20,2 трлн/рік. Визначена вартість глобальних ЕП майже в 4,5 рази перевищує вартість валового світового продукту в 2000 р. при глобальному ВВП у \$75 трлн/рік і вартості ЕП \$347 трлн/рік.

За результатами аналізу динаміки вартості послуг глобальної екосистеми впродовж 19952015 pp. (Sannigrahi et al., 2018) виявлено втрату \$1,21 млрд, яка свідчить, що лісові землі, водноболотні угіддя та водні об'єкти є найуразливішими екорегіонами (табл.).

Способи вартісного оцінювання ЕП та їх класифікація є сталими, проте критерії визначення набору оцінюваних ЕП залежно від типу природокористування території дотепер не вироблені й залежать найчастіше від наявних даних, хоча насамперед мало б враховуватися основне функціональне призначення території (Bodrov, 2016). 
Динаміка вартості послуг глобальної екосистеми (Sannigrahi et al., 2018)

Таблиця

\begin{tabular}{lccc}
\hline \multirow{2}{*}{ Тип землекористування (земельного покриття) } & \multicolumn{3}{c}{ Загальна вартість ЕП на роки, трлн дол. } \\
\cline { 2 - 4 } Загальна вартість ЕП, у т.ч.: & 1995 & 2015 & різниця \\
\hline орні землі & 58,97 & 57,76 & $-1,21$ \\
міське покриття & 4,80 & 4,90 & $+0,10$ \\
ліси & 0,30 & 0,59 & $+0,29$ \\
луки & 17,59 & 17,42 & $-0,17$ \\
водно-болотні угіддя & 9,10 & 8,90 & $-0,20$ \\
водні об’єкти & 22,19 & 21,11 & $-1,08$ \\
\hline
\end{tabular}

Найпростіший спосіб визначення вартості сумарних ЕП території може бути зведений до визначення iï частки в загальній площі Землі i, пропорційно, в \$33 трлн (Rozenberh, 2014). Крім глобального оцінювання ЕП, $є$ приклади прямих регіональних оцінювань.

Республіка Білорусь, яка у рейтингу країн за індексом екологічної ефективності за останні роки піднялася на 41 позицію й посіла 32 місце серед 178 держав (Trusova, 2016). Проте іiі екологічний слід становить 4,1 га на особу, що в 1,5 раза перевищує середньосвітове значення. Серед напрямів досліджень ЕП, що отримали розвиток у Білорусі, виділяють дослідження ЕП природних (природнотехногенних) комплексів в умовах міст і в приміських зонах. 3 метою визначення монетарної вартості ЕП для прийняття управлінських рішень в екологічній сфері, в Білорусі розроблено нормативний документ «Методика визначення вартісного оцінювання екосистемних послуг і біологічного різноманіття».

Натомість екологічна ситуація в Росії, на думку Rozenberh (2014), вийшла 3-під контролю й потребує рішучої екомодернізації держави та суспільства в інтересах екологічно стійкого розвитку країни та забезпечення екологічного благополуччя населення. Характерним є досить самобутній підхід до трактування результатів досліджень російськими вченими 3 наголосом на винятковій забезпеченості власної країни природним капіталом. Зазначено, що екологічний слід Росії становить 4,0 га на людину, тоді як доступна біомісткість становить 6,6 (з цієї позиції запас доступної біомісткості мають Росія, Естонія, Литва, Латвія, Казахстан, Киргизстан) і розглядають можливість використання показників біомісткості та екологічного сліду для оцінювання інвестиційної привабливості регіонів. Наразі визнано, що в Росії ставлення громадян до екологічного боргу перед майбутнім перебуває на дуже низькому рівні (Rozenberh, 2014), але залежність якості життя та економіки від «природного капіталу» вимагає його збереження, зокрема оцінювання і формування системи взаємин між людиною і природою. Загалом визнано декілька незалежних підходів у визначенні цінностей природних ресурсів, хоча всі вони мають високий сту- пінь невизначеності. Наразі застосовувані в Росії методики грунтуються на визначенні економічного збитку від дії забруднення на конкретні види реципієнтів шляхом підсумку складових втрат у грошовому вигляді. Такі методики активно застосовують й у західних країнах, де вони базуються на статистичному підході, методі контрольних районів і методах соціологічних обстежень, що не дає змоги отримати узагальнені оцінки для територій.

Під час розрахунків Costanza et al. (1997) припускають постійну одиницю вартості на гектар певного типу екосистеми і множать це значення на площу кожного типу для досягнення сукупних підсумків. Підрахунок можна дещо поліпшити коригуванням значень за допомогою експертної оцінки місцевих умов (Batkeretal, 2008) й перевести в долари США на основі паритету купівельної спроможності (ВСП). Значення на 1 га у середньому у вісім разів перевищують еквівалент оцінки Costanza et al. (1997). Такий підхід використовували у розрахунках загальної вартості ЕП й іншими дослідниками, у тому числі для міських територій (Cen et al., 2015), розподілених на чотири типи землекористування: забудовані землі (з нульовою вартістю ЕП), води, ліси, сільськогосподарські угіддя. За аналогічним експертним оцінюванням ЕП трансферним методом оцінено вартість ЕП біоми басейну р. Дніпро та біоми Київської області станом на 2011 рік. Встановлено, що вартість ЕП Київської області майже вдвічі перевищує створюваний річний валовий продукт (Veklych, 2018).

Оцінено загальну економічну вартість ЕП з 1 га землі (Strokov \& Poleshkina, 2016). Зазначено, що наразі ще не вироблено єдиного підходу до оцінювання вартості ЕП різних екосистем і тому досить складно точно оцінити збитки, які несе людство від трансформації природних екосистем у культурні. Потребує вдосконалення й методика екологоекономічного оцінювання біорізноманіття лісів.

Minin (2014) повідомляє, що затверджених методик оцінювання ЕП у містах немає, в основному все зводиться до оцінювання збитків для різних компонентів природного середовища від окремих видів впливів, однак розпочато розробку наукового обгрунтування щодо проведення оцінювання ЕП зелених насаджень м. Москви. 
Землекористування (земельне покриття) у містах змінюється внаслідок міської експансії, економічного розвитку та швидкого зростання населення (Lin, 2018). Кількісний аналіз цих змін важливий для вивчення впливу на вартість ЕП, що допомагає у прийнятті правильних рішень та збереженні екосистем. Виявлено безперервне зниження загальної вартості ЕП за період 1992-2018 рр., зумовлене значною втратою сільськогосподарських та лісових земель. Встановлено, що перехід до іншого типу землекористування $1 \%$ землі може призвести до змін у 0,28-0,50\% вартості ЕП упродовж десятилітнього терміну, що необхідно враховувати в управлінні земельними ресурсами та в розробленні стратегії щодо збереження рівня ЕП.

За опублікованими даними (Zhang, 2018), серед ЕП найчутливішим до зростання урбанізації $є$ збереження біорізноманіття, за яким слідує відпочинок на свіжому повітрі, стік води, продуктивність зерна, зберігання вуглецю та запобігання ерозії. Просторове вивчення взаємозв'язків між ЕП та урбанізацією дає змогу розробити практичні рекомендації щодо планування міського розвитку та охорони навколишнього середовища.

Антропогенний вплив на території, схильні до зміни землекористування, позначається і на обсягах ЕП (Erokhova \& Vasenev, 2018). Основною проблемою зміни типу землекористування, а як наслідок - і обсягів ЕП, $є$ відсутність структурованої методики проведення досліджень для прогнозування сценаріїв розвитку, за яких відбувається збереження і збільшення обсягів ЕП. Автори розглянули основні категорії ЕП та обгрунтували основні методи оцінювання різних ЕП для міських територій. Наведено принцип вибору територій для організації міського сільського господарства, який грунтується на аналізі сучасних тенденцій урбанізації. Доведено, що створення зон міського сільського господарства $є$ одним із найефективніших варіантів збереження обсягів ЕП у містах. Зазначено, що для сталого розвитку міських екосистем необхідно враховувати їх особливості на стадії планування забудови міських територій. Крім того, оцінка ЕП в містах повинна враховувати багатофункціональність землекористування і ступінь сумісності конкуруючих за територію видів землекористування. Водночас потрібно враховувати типи і категорії будь-якого міського зеленого простору (Yukhnovskyi \& Zibtseva, 2018a), що, насамперед, потребує осучаснення класифікації міських зелених насаджень (Yukhnovskyi \& Zibtseva, 2018b) та впровадження нормативів 3 позицій отримання максимальної кількості ЕП.

Результати досліджень щодо розрахунку сумарної вартості ЕП українських міст нам не траплялись, хоча вчені зазначають необхідність урахування того, що в міських умовах ЕП надають не лише зелені насадження, але й певні урболандшафти. Boulton et al. (2018) вважають, що тенденція розквіту паркового та зеленого просторів впродовж останніх двох десятиліть може відображати сут- тєве зростання кількості міського населення та супутній тиск на земельні ресурси, включаючи зелені простори. Причому міське зелене середовище, зазвичай, планується 3 використанням рекреаційних стандартів, незважаючи на збільшення вимог до функцій, ЕП та переваг екосистем. Sulkarnaeva (2018) зауважує, що і зарубіжні, і російські методики оцінювання ЕП для всього міста $є$ складно застосовуваними й для них необхідні докладні дані про структуру зелених насаджень, їх вік, стан, періоди вегетації, стан грунтового покриву. Визначення того, як закономірності постачання ЕП пов'язані із структурою та складом рослинності в міських зелених насадженнях, може сприяти збільшенню обсягів ЕП (Graçaa et al., 2018). Вони дослідили вплив різних типів міських зелених насаджень на ЕП в місті Порту та визначили залежність змін від соціально-економічного градієнта.

Загалом сформувалося декілька напрямів практичного застосування оцінювання ЕП (Titova, 2015), основними 3 яких є використання результатів: у національних системах комплексного еколого-економічного обліку; під час розроблення національної екологічної політики та довгострокових програм і планів охорони навколишнього середовища і природокористування (вибір напрямків екологічно безпечного розвитку і зниження рівня екологічних загроз); для встановлення платежів за ЕП; під час формування ринків ЕП. Значного прогресу досягнуто у визначенні, кількісному оцінюванні ЕП міських екосистем (Graçaa et al., 2018), але ці знання залишаються майже не реалізованими в міському плануванні та в управлінні.

Серед індикаторів сталого розвитку ООН лісистість вважають показником, пов'язаним із екологічною стійкістю, який може бути співвіднесений iз ЕП. Зелена інфраструктура є чинником забезпечення сталого розвитку міста, а показники озеленення (забезпеченість насадженнями, стан і стійкість насаджень до міського середовища) входять у групу індикаторів стійкого розвитку (Morozova \& Debelaya, 2018). Головною функцією зеленої інфраструктури (або екологічного каркасу міста) є максимальне зниження впливу антропогенного чинника i посилення впливу природного потенціалу міста, завдяки чому вона акцентує увагу на екологічному значенні території, розглядає весь спектр ландшафтних змін i слугує основою для формування $\mathrm{i}$ розвитку Генерального плану міста. Розрахунок динаміки вартості ЕП, спряженої із динамікою землекористувань, дало б змогу запобігти прийняттю не екозбалансованих рішень щодо перспективного розвитку міської території. Дієвим практичним заходом видається сувора регламентація загальновідомого містобудівного показника - рівня озеленення як додаткового містобудівельного обмеження, що сприяло б збереженню наявних екостабілізаційних просторів.

Зазначено, що певний ризик для ефективного впровадження підходу ЕП у територіальне планування створює міжвідомчий характер проблеми: 
регулювання діяльності 3 ідентифікації та оцінювання ЕП Міністерством екології, тоді як територіальне планування контролюється Міністерством регіонального розвитку (Kruhlov, 2014).

Висновки i перспективи. За результатами аналізу впровадження оцінювання ЕП в Україні з'ясовано, що розуміння того, як зміни в землекористуванні впливають на ЕП, не досконале. Перехід від екологічних основ оцінювання впливу до економічних розрахунків потребує не тільки ретельного контролю, але й, насамперед, відповідної бази даних. 3 огляду на останнє та 3 позицій зручності виконання розрахунків, вважаємо за доцільне на першому етапі інтеграції підходу оцінювання ЕП міських екосистем у генеральному плануванні міст використовувати трансферний метод з розрахунком загальної вартості ЕП для різних типів землекористування. Однаковий підхід дасть змогу отримати порівнювані результати й відстежувати відповідні зміни, що слугуватиме підгрунтям для уточнення перспективних містобудівних планів. Джерелами даних можуть бути матеріали генеральних планів міст (за умови їх актуальності та достатньої якості), стандартні статистичні землевпорядні форми щодо розподілу земель територіально-адміністративних одиниць та доступні супутникові дані.

У містобудівне проектування України необхідно інтегрувати ландшафтне планування, яке слугуватиме підосновою планування сталого розвитку. Для містобудування пріоритетним має бути питання збереження природних ландшафтів та їх властивостей. Вважаємо за доцільне, за аналогією з лісистістю, використання показника «рівень озеленення міста» для обгрунтування екологічної компоненти містобудування під час генерального планування міських територій.

Впровадження концепції екосистемних послуг у територіальне планування забезпечить ефективну міжвідомчу координацію між екологічними і містобудівними установами.

\section{Бібліографічні посилання}

Batker, D., Batker, D., Swedeen, P., Costanza, R., de la Torre, I., Boumans, R.,... Bagstad, K. (2008). A New View of the Puget Sound Economy: The Economic Value of Nature's Services in the Puget SoundBasin. Earth Economics, Tacoma, WA, 90.

Bodrov, K., Yakovlev, A., \& Semeniuk, O. (2016). Assessment of ecosystem services of specially protected and park areas. Use and protection of natural resources in Russia, 2, 62-68 (in Russian).

Boulton, C., Dedekorkut-Howes, A., \& Byrne, J. (2018). Factors shaping urban green space provision: Asystematic review of the literature. Landscape and Urban Planning, 178, 82-101. https://doi. org/10.1016/j.landurbplan

Cen, X., Wu, C., Xing, X., Fang, M., Garang, Z., \& Wu, Y. (2015). Coupling Intensive Land Use and Landscape Ecological Security for Urban Sustainability: An Integrated Socioeconomic Data and Spatial Metrics Analysis in Hangzhou City. Sustainability, 7, 1459-1482.

Costanza R., d'Arge R., de Groot R., Farberk, S., Grasso, M., Hannon, B., ...Belt, M. (1997). The value of the world's ecosystem services and natural capital. Nature, 387, 253-260.

Costanza, R., Groot, R., Sutton, P., Ploeg, S., Anderson, S., Kubiszewski, I., ...Turner, R. (2014). Changes in the global value of ecosystem services. Global Environmental Change, 26, 152-158. https:// doi.org/10.1016/j.gloenvcha

Erokhova, V., \& Vasenev, V. (2018). Prospects of use of ecosystem services for estimation of scenarios of urban development. RUDN Journal of Agronomy and Animal Industries, 13 (2), 113-120. https://doi. org/10.22363/2312-797X-2018-13-2-113-120 (in Russian).

Graçaa, M., Alvesa, P., Gonçalvesa, J., Nowakc, D. J., Hoehnc, R., Farinha-Marquesa, P., ...Cunha, M. (2018). Assessing how green space types affect ecosystem services delivery in Porto, Portugal. Landscape and Urban Planning, 170, 195-208. https://doi.org/10.1016/j.landurbplan

Grunewald, K., \& Bastian, O. (2014). Bewertung von ÖSD in Naturschutzgebieten und Agrarlandschaften Methodik und Fallbeispiele. Erfassung und Bewertung von Ökosystem dienstleistungen. Bonn, 238-263.

Haines-Young, R., \& Potschin, M. B. (2017). Common International Classification of Ecosystem Services (CICES) V5.1 and Guidance on the Application of the Revised Structure. Available from www.cices.eu

Koniushkov, D. (2015). Formation and development of the concept of ecosystem services: a review of foreign publications. Bul. Soil Inst., 80, 26-49 (in Russian).

Kononenko, O. (2013). Human-geographical bases of formation and development of "green economy» in Ukraine. Economic and social geography, 1 (66), 106-114 (in Ukrainian).

Kruhlov, I. (2018). Prospects for the implementation of an ecosystem services approach in territorial planning in Ukraine. Sustainable development - XXI century: management, technology, models. Kyiv Polytechnic Institute. 341-353 (in Russian).

Lin, X. J., Xu, M., Cao, C.X., Singh, R., Chen, W., \& Ju, H. R. (2018). Land-Use/Land-Cover Changes and Their Influence on the Ecosystem in Chengdu City, China during the Period of 1992-2018. Sustainability, 10 (10), 3580. https://doi.org/10.3390/su10103580

Millennium Ecosystem Assessment (2005). Ecosystems and Human Well-being: Multiscale Assessment. Millennium Ecosystem Assessment Series, 4, Washington DC: Island Press. Google Books.

Minin, A. (2014). Sustainable development of Moscow and ecosystem services of its natural territories. Bulletin "On the way to sustainable development of Russia», 69, 9 (in Russian).

Morozova, G., \& Debelaya, I. (2018). Green Infrastructure as a Factor for Sustainable 
Development of Khabarovsk. Economics of region, 14 (2), 562-574. https://doi.org/10.17059/2018-2-18 (in Russian).

Pakhomov, A., Bulakhov, V., Pysarenko, P., Zhukov, O., Kunakh, O., Goloborodko, K., ... Brygadyrenko, V. (2018). Ecosystem services in the context of global climate change and sustainable development of Ukraine's natural potential. http://www.kdpu-nt. gov.ua/sites/default/files/ referat_roboti_4.pdf (in Ukrainian).

Rozenberh, A. (2014). Assessment of ecosystem services for the territory of the Samara region. Volga ecological journal, 1, 139-145 (in Russian).

Sannigrahi, S., Bhatt, S., Rahmat, S., Paul, S. K., \& Sen, S. (2018). Estimating global ecosystem service values and its response to land surface dynamics during 1995-2015. Journal of environmental management, 223, 115-131. https://doi.org/10.1016/j. jenvman.2018.05.091

Soloviy, I. (2016). Evaluation of forest ecosystem services provided by forests of Ukraine and proposals on PES mechanisms. https://www.ioer.de/fileadmin/ internet/IOERProjekte/PDF/FB L/OESD/TEEBproces_v_Ukrajini.pdf (in Ukrainian).

Sotnyk, I., \& Mogilenets, T. (2011). Analysis of approaches to the economic valuation of ecosystem services. Mechanism of regulation economics, 2, 152-158. (in Russian).

Strokov, A., \& Poleshkina, I. (2016). Economic evaluation of ecosystem services in Tavushskaya oblast' of Armenia. Agricultural and Resource Economics: International Scientific E-Journal, 2 (1), 110-131. Available at: www.arejournal.com (in Russian).

Sukhdev, P., Wittmer, H., Schröter-Schlaack, C., Nesshöver, C., Bishop, J., Brink, P., ...Simmons, B. (2010). The Economics of Ecosystems and Biodiversity: Mainstreaming the Economics of Nature. A synthesis of the approach, conclusions and recommendations of TEEB, 39.

Sulkarnaeva, L. (2018). Adaptation of the concept of ecosystem services for Russian cities. Successes of modern natural science, 12 (1), 207-210. https://doi. org/10.17513/use.36998 (in Russian).

Titova, H. (2015). Ecosystem services valuation: a potential application in practice. Proceedings of the Trans-Baikal State University, 3 (118), 179-191 (in Russian).

Trusova, V. (2016). Ecosystem services in the transition to a «green economy». Proceedings of Belarus State University, 8, 227-230. http://elar.urfu.ru/ bitstream/10995/43599/1/kie_2016_01_52. pdf (in Russian).

Veklych, O. (2018). The urgency of taking into account the value appraisal of ecosystem services of the territory. Sustainable development - XXI century: management, technology, models. Kyiv Polytechnic Institute, 518-526 (in Ukrainian).

Zhang, Y., Liu, Y. F., Zhang, Y., Liu, Y., Zhang, G. X., \& Chen, Y.Y. (2018). On the spatial relationship between ecosystem services and urbanization: Acasestudyin Wuhan, China. Science of the total environment, 637, 780-790. https://doi.org/10.1016/j.scitotenv

Yukhnovskyi, V., \& Zibtseva, O. (2018a). Comparative analysis of classification of plantations of settlements of Ukraine and post-Soviet countries. Proceedings of the Forest Academy of Sciences of Ukraine, 16, 9098. https://doi.org/10.15421/411810 (in Ukrainian).

Yukhnovskyi, V., \& Zibtseva, O. (2018b). Typology and classification as methods of categorization of green space categorization. Proceedings of the Forest Academy of Sciences of Ukraine, 17, 53-62. https:// doi.org/10.15421/411820 (in Ukrainian).

\section{Оценка экосистемных услуг \\ в генеральном планировании городских территорий}

\author{
В.Ю. Юхновский ${ }^{1}$ О. В. Зибцева
}

На основе анализа литературных источников и генеральных планов развития городов выявлено современное состояние и уровень внедрения концепции экосистемных услуг в градостроительном планировании Украины и намечены перспективы его интеграции и развития. Обоснована координация генерального планирования с динамикой трансформации землепользования городских территорий и стоимостью их экосистемных услуг.

Отмечено, что оценки экологических услуг проводятся в трех направлениях: экологическом, экономическом и социальном. Для каждой группы экосистемных услуг применяют свои методы экономической оценки. Так, обеспечивающие экосистемные услуги оценивают преимущественно по их рыночной стоимости, регулирующие - методами «предотвращения и замещения расходов», культурные - методом «расходов на путешествие» и другими.

По результатам анализа динамики стоимости услуг глобальной экосистемы за период 1995-2015 гг. установлена потеря \$ 1,21 млрд, что свидетельствует о чрезвычайной уязвимости экорегионов, в составе которых доминируют

Юхновский Василий Юрьевич - академик Лесной академии наук Украины, доктор сельскохозяйственных наук, профессор кафедры возобновления лесов и лесных мелиораций. Национальный университет биоресурсов и природопользования Украины, ул. Генерала Родимцева, 19, г. Киев, 03041, Украина. Тел.: +38-067-720-32-16. E-mail: yukhnov@ukr.net ORCID: http://orcid.org/0000-0003-3182-4347

Зибцева Ольга Васильевна - кандидат сельскохозяйственных наук, доцент кафедры ландшафтной архитектуры и садовопаркового строительства. Национальный университет биоресурсов и природопользования Украины, ул. Генерала Родимцева, 19, г. Киев, 03041, Украина. Тел.: +38-050-835-77-74. E-mail: stplut2017@gmail.com ORCID: http://orcid.org/00000003-0706-0738 
экостабилизурующие угодья - леса, луга, пастбища, воды.

Украина по вопросам оценки и учета экосистемных услуг находится в самом начале процесca: в отличие от большинства стран, в Украине нет Национальной стратегии биоразнообразия, терминология и методики в сфере экологии формировались еще в советское и постсоветское время и пока что не всегда гармонируют с западными подходами и концептами. Довольно ограничена база исходных данных, что является первоочередной проблемой в осуществлении расчетов стоимости экосистемных услуг.

По результатам анализа уровня внедрения оценки экосистемных услуг в Украине установлено, что понимание того, как изменения в землепользовании влияют на экосистемные услуги, далеко не совершенно. Переход от экологических основ оценки воздействия к экономическим расчетам требует не только тщательного контроля, но и, прежде всего, соответствующей базы данных. Учитывая последнее и с позиций удобства выполнения расчетов, считаем целесообразным на первом этапе интеграции подхода оценки экосистемных услуг городских экосистем в генеральное планирование городов использование трансферного метода с расчетом общей стоимости экосистемных услуг для различных типов землепользования. Одинаковый подход позволит получить сопоставимые результаты и отслеживать динамику изменений, что создаст почву для усовершенствования перспективных градостроительных планов. Источниками данных могут служить материалы генеральных планов городов, стандартные статистические землеустроительные формы по распределению земель территориально-административных единиц и доступные спутниковые данные. В градостроительное проектирование Украины необходимо интегрировать ландшафтное планирование, что послужит подосновой планирования устойчивого развития. Особо целесообразным для градостроительства является решение в рамках городского планирования вопросов сохранения природных ландшафтов и их свойств.

Обоснована необходимость гармонизации национального экологического законодательства с европейскими стандартами, внедрение экосистемного подхода в территориальный менеджмент, где оценка стоимости экосистемных услуг должна стать неотъемлемым атрибутом территориального планирования. Учитывая, что среди индикаторов устойчивого развития ООН есть ряд показателей, связанных с экологической устойчивостью природных комплексов, соотнесенных с экосистемными услугами (лесистость), обосновано атрибутивность введения уровня озеленения города как альтернативного нормативного показателя и градостроительного ограничения для генерального планирования городских территорий.

Ключевые слова: устойчивое развитие; стоимость экосистемных услуг; зеленое пространство; озеленение.

\section{Assessment of ecosystem services within the framework of general planning of urban areas}

\author{
V. Yukhnovskyi', O. Zibtseva ${ }^{2}$
}

Based on the analysis of literary sources and master plans for cities development, the current state and level of the concept of ecosystem services implementation in the urban planning in Ukraine is revealed, and prospects for its integration and development are outlined. The coordination of general planning with the dynamics of the land use transformation in urban areas and the value of ecosystem services has been substantiated.

It is noted that the assessment of ecosystem services are conducted in three fields : environmental, economic and social. For each group of ecosystem services, appropriate economic valuation methods applied. Thus, provisioning services are valued primarily by their market value, and those that regulate them - by means of «prevention and replacement of costs», and cultural ones - by the method of «travel costs».

Assessment of the dynamics of the global value of ecosystem services for the period 1995-2015 showed a loss of $\$ 1.21$ billion, which indicates the greatest vulnerability of ecoregions, which are dominated by ecologically stabilizing lands: forests, meadows, pastures, and water.

Ukraine is at the very beginning of the process on the issue of implementing system for accounting of ecosystem services. Unlike most countries, the terminology and methodologies in the field of ecology were formed in Soviet and post-Soviet times and are not always in harmony with western approaches and concepts. A rather limited is the baseline data base, which is the primary problem in the implementation of ecosystem services calculations.

An analysis of the implementation of the evaluation of ecosystem services in Ukraine showed that understanding how changes in land use affect ecosystem services is not perfect. The transition from the environmental bases of impact assessment to economic calculations requires not only careful monitoring, but, above all, an appropriate database. Considering the latter, and from the standpoint of ease of calculation, we consider it's appropriate at the first stage of integrating the ecosystem services assessment

\footnotetext{
Vasyl Yukhnovskyi - a full Member of the Forest Academy of Sciences of Ukraine, Doctor of Agricultural Sciences, Professor of the department of forests restoration and forest meliorations. National University of Life and Environmental Sciences of Ukraine, st. General Rodimtsev, 19, Kyiv, 03041, Ukraine. Tel.: +38-067-720-32-16. E-mail: yukhnov@ukr.net ORCID: http://orcid.org/0000-0003-3182-4347

Olga Zibtseva - Candidate of Agricultural Sciences, Assistant professor of the department of landscape architecture and gardening. National University of Life and Environmental Sciences of Ukraine, st. General Rodimtsev, 19, Kyiv, 03041, Ukraine. Tel.: + 38-050-835-77-74. E-mail: stplut2017@gmail. com ORCID: http://orcid.org/0000-0003-0706-0738
} 
approach of urban ecosystems into urban master planning using the transfer method with the calculation of the total assessment of ecosystem services for various types of land use. The same approach will provide comparable results and track the dynamics of change, which will create the ground for editing promising urban planning plans. Data sources may include materials of master plans for cities, standard statistical land use forms for the distribution of land of territorial-administrative units and satellite data are available. Ukraine needs to integrate landscape planning into town planning design, which will serve as a basis for sustainable development planning. For urban planning, it is particularly appropriate to address issues of preserving natural landscapes and their properties within the framework of urban planning.
The necessity of harmonization of national environmental legislation with European standards, the introduction of the ecosystem approach in territorial management, where the definition of ecosystem services should become an integral attribute of spatial planning, is substantiated. Considering that among the UN sustainable development indicators there are a number of indicators related to the environmental sustainability of natural complexes (forest cover), correlated with ecosystem services, the attribute is justified to introduce an alternative standard indicator for general planning of urban areas - the level of greening the city.

Key words: sustainable development; cost of ecosystem services; green space; greening. 